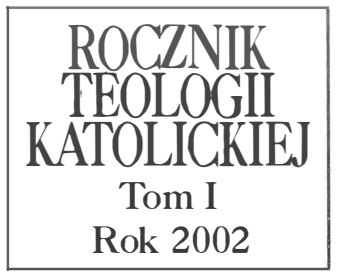

Ks. Jerzy Lewandowski

UKSW Warszawa

\title{
WSKAZANIA PRYMASA TYSIĄCLECIA DLA NARODU POLSKIEGO
}

Z całej teologicznej wizji narodu polskiego, jego historycznej egzystencji głoszonej przez księdza prymasa S. Wyszyńskiego, przebija w sposób subtelny teologicznie poprawne, eklezjalne przesłanie o charakterze mesjanistycznym. Należy to od razu zauważyć, że tego rysu mesjanistycznego (w poprawnym znaczeniu) nie da się wyraźnie wydzielić z całości poglądów Kardynała. Naród polski, jak każdy naród, ma dwa aspekty swego życia i swej historii: aspekt ogólnoludzki i ogólnokościelny oraz swój własny szczególny aspekt ludzki i chrześcijański, a więc swój osobisty profil, postać, kształty, losy, niepowtarzalny i jedyny wyraz w każdej dziedzinie.

\section{Kościół „duszą” narodu}

Sobór Watykański II uczy, że Kościół służy pomocą poszczególnym ludziom, całym społeczeństwom oraz aktywności ludzkiej (KDK 4o). Sobór miał na myśli społeczeństwo w ogóle, ale w nauczaniu Prymasa Polski uwagi te należałoby odnieść przede wszystkim do narodu.

Prymas Polski kładł większy nacisk na nadprzyrodzony charakter chrześcijaństwa i na jego „pomocniczość” pośrednią. Kościół właśnie jest transcendentny w stosunku do narodu i całej doczesności. „Nawet wtedy - przemawiał Ksiądz Prymas - gdy znajduje się na płaszczyźnie międzynarodowej, jest przede wszystkim Kościołem, to znaczy przedstawicielem ładu wyższego niż ład doczesny, materialny, ziemski. Przedstawiciele wszystkich państw obradujących w Helsinkach nie są w stanie zagwarantować swoim obywatelom 
życia wiecznego. Może to uczynić tylko przedstawiciel Kościoła, który jest i działa na tej ziemi, ale prowadzi do Ojczyzny Niebieskiej. Stąd nadrzędność Kościoła - nie w sensie prawnym, lecz religijnym, nadprzyrodzonym, moralnym, nad wszelkimi formami życia społecznego, politycznego, państwowego czy narodowego" ${ }^{1}$. Ale Prymas Polski zawsze był daleki od rozdzielania Kościoła od narodu, uważając je za wartości relacyjne i wzajemnie sprzężone.

A zatem nie tyle różnią się kultury między sobą: doczesna i katolicka, i walczą między sobą, ile raczej różnią się „umysły i serca” ludzi, którzy tworzą wspólną kulturę i wspólnie w niej żyją. Różnica jest wewnątrz człowieka, nie w samym zjawisku kultury.

Kardynał Wyszyński z niezwykłą gorliwością bronił praw narodu do wyznawania Boga i do kultury chrześcijańskiej. Wobec przemocą narzuconej laicyzacji i ateizacji naród stanął jakby na przełęczy chrześcijańskiej kultury narodowej i obcej duchowości Polaków pseudokultury materialistycznej w Polsce, w której Ksiądz Prymas upatrywał źródeł nihilizmu, a w konsekwencji nienawiści społecznej. Obronił w końcu Ojczyznę przed największym niebezpieczeństwem: utraty wiary w Boga Żywego; w tym wymiarze jego duchowość promieniuje najpotężniej i staje się trwałym dobrem wszczepionym w dzieje narodu.

Ksiądz Prymas oceniał zawsze negatywnie odsuwanie Boga i idei Kościoła od serc wierzących i tworzenia kultury sprzyjającej ateizmowi. Oczywiście przyjmował starochrześcijańską tezę, że ateizm niszczy samą istotę prawidłowego życia społecznego, a więc i narodu. Stąd w dłuższej perspektywie, ateizm i naród nie wiążą się ze sobą pozytywnie, tak jak wiążą się ze sobą Kościół i naród. „Dlatego Kościół broni i przestrzega - mówił Kardynał - przed ateizacją, czyli bezbożnictwem, które jest straszliwą trucizną i chorobą duchową, intelektualną" 2 .

Prymas opierał się w swym nauczaniu na wielkim uznaniu dla doczesnych wartości narodu, ale uznawał, że naród i Kościół wzajemnie się potrzebują. Podkreślał zwłaszcza potrzebę harmonii i zgody, która wyrasta z idei klasycznej. Kościół wspierał i pielęgnował takie wartości narodu, jak jedność, więzi wspólnotowe, miłość wzajemną, moc ducha, idee szlachectwa duchowego: „Kościół wzniósł nowe - przemawiał Kardynał - chrześcijańskie obyczaje, gdy poprzez ziemię polską szło nowe. Dając nowego ducha członkom naszego narodu, Kościół wiązał nas, zespalał i jednoczył mocami

1 S. Wyszyński, Polityka Kościoła - to wyznanie Chrystusa przed ludźmi, Warszawa-Miodowa, 3 VIII 1975, t. LI, s. 6.

2 S. Wyszyński, Wczoraj, dziś i jutro Polski katolickiej, Gniezno, 26 IV 1964, t. XVIII, s. 4 . 
nadprzyrodzonymi. [...] Dzięki temu przyrodzona więź została jeszcze bardziej wzmocniona, co miało znaczenie dla naszego życia rodzinnego, społecznego, narodowego i nawet państwowego. Szlachetne i wartościowe właściwości naszego narodu zostały jeszcze spotęgowane i wzmocnione przez ducha chrześcijańskiego" 3 .

Dzięki przenikaniu Kościoła do wszystkich przejawów życia narodowego tworzy się „religijna dusza” narodu, stanowiąca twór naturalny, lecz udoskonalany przez Kościół: „Przez nauczanie Kościoła - powiedział Prymas Kościół w Ojczyźnie naszej wypełnia zadanie kształtowania duszy nie tylko poszczególnych Polaków, ale - duszy narodu, który przez swoje ochrzczone dzieci stwarza chrześcijańską atmosferę życia społecznego i publicznego. Naród pielęgnowany w promieniach Ewangelii jest narodem chrześcijańskim, jakiego pragnął Chrystus" 4 .

\section{Pasterska funkcja Kościoła w narodzie}

Prymas Polski podkreślał, że podstawowym zadaniem Kościoła jest spełnianie funkcji pasterskiej. Nie jest to oczywiście dążenie do przywództwa politycznego, społecznego, kulturalnego, lecz wypełnienie misji zbawczej. Pasterzowanie Kościoła w narodzie to prowadzenie go ku zbawieniu, doskonałości i rozwojowi religijnemu. Ale to duszpasterzowanie ściśle religijne posiada jednocześnie pewien aspekt doczesny, który wychodzi na korzyść obecnemu życiu narodowemu. W Kościele bowiem jest niezwykła moc harmonizowania porządku stworzonego i zbawczego, natury i łaski oraz spraw ludzkich i Bożych. A ta siła znaczy więcej niż systemy polityczne, gospodarcze lub ideologiczne. W ten sposób dochodzi do głosu idea Kościoła jako „dobrego pasterza”. „Kościół, jako Pasterz dobry - mówił Prymas Polski - naśladuje Chrystusa, jest wraźliwy na człowieka i jego prawa. Dlatego, gdy coraz częściej godność człowieka nie jest uszanowana, gdy prawa osoby ludzkiej i narodu są gwałcone - w takiej sytuacji Kościół musi wołać, że jednak najważniejszą wartością na ziemi jest człowiek" 5 .

Funkcja pasterzowania konkretyzuje się najbardziej w osobach biskupów i kapłanów. Od wiary, miłości, postawy i służby kapłanów zależy właściwy

3 S. Wyszyński, Te Deum w Grodzie Kopernika, Frombork, 19 VI 1966, t. XXIV, s. 3.

4 S. Wyszyński, Z Mazowieckiej kotyski - na ottarz!, Rostowo, 20 VIII 1967, t. XXVII, s. 4 .

5 S. Wyszyński, Jak rozumiemy normalizacje w naszej Ojczyźnie, Kraków - Skałka, 9 V 1971, t. XXXVII, s. 7. 
rozwój nadprzyrodzony społeczności narodu. Tutaj Kościół czyni z kapłanów uczestników specjalnych pasterskich misji, przede wszystkim ustanawia ich obrońcami praw człowieka i narodu. Kapłani stoją na straży godności człowieka, jego wolności, sprawiedliwości i sensu życia społecznego. Jeśli bronią dobra Kościoła, to tym samym bronią dobra narodu. Hierarchia Kościoła jest błogosławieństwem i dla doczesnego życia narodowego. „Obecność hierarchii - nauczał Prymas Polski - w życiu narodu, jest dla narodu błogosławieństwem. Przez moce nadprzyrodzone tworzy ona jedność narodu, więzy przyrodzone potęguje przez więź nadprzyrodzoną. Tworzy jedność prawdy, myśli, światopoglądu oraz wyrastającej z nich kultury religijnej i narodowej. Tworzy też pokój, bo naród zespolony przez jeden Chrzest w jednej wierze, ma w sobie znamiona i ducha pokoju" ${ }^{6}$. Posiadają oni zatem pewną misję społeczną, która wypływa z ich misji czysto kościelnej. W ten sposób Kościół ma za zadanie troszczyć się o „narodową rację stanu”, która jest wartością bardzo głęboką. Naród jest wartością Bożą, nieprzemijającą i znajduje się w istotnym miejscu w Bożej ekonomii świata, dlatego jego interes, jako interes osób narodu, jest daleko istotniejszy niż interes polityczny, ekonomiczny czy ustrojowy. Z Boga i tylko z Boga wynikają wszelkie dobra doczesne: społeczne, polityczne, gospodarcze. Jest to interes „społeczności osób Bożych”. „W tej drodze - przemawiał Ksiądz Prymas - Kościół stale nam towarzyszy i pragnie by coraz bardziej zacieśniała się nadprzyrodzona wspólnota wszystkich dzieci Bożych. W tym duchu Kościół - stając w obronie wolności w ogóle, sprawiedliwości, rozwoju moralnego, kultury religijnej - staje w obronie narodowej racji stanu" 7 .

„Wiara narodu” jest najwyższym dobrem. „Wspomnijmy - nauczał Kardynał - Rok Tysięczny i wielki napór niemczyzny na młode państwo Mieczysława i Bolesława Chrobrego. [...] Najboleśniejsze jednak a zarazem najchwalebniejsze w dziejach naszych są czasy rozbiorów, czasy niewoli narodu i niezwykłego ograniczenia Kościoła przez zaborców: Niemców i Moskali [...]. Wspominamy dzisiaj przeżycia rodaków w obozach koncentracyjnych. A gdybyśmy tak obliczali ilu kapłanów w obronie wiary i narodu powędrowało na Sybir i do więzienia? [...]. Wszystko to minęło, a Kościół i naród pozostał [...]. Zachowało się największe dobro religijne i narodowe wiara narodu" 8 .

6 S. Wyszyński, Stów kilka o potędze Stowa Bożego w życiu Narodu, Warszawa - Bazylika Archikatedralna Jana, 24 VI 1966, t. XXIV, s. 3-4.

7 S. Wyszyński, Kościót nie walczy z władza tylko jej nadużyciami, Kraków - Skałka, 11 V 1975, t. L, s. 6-7.

8 S. Wyszyński, W stużbie religijnej i narodowej racji stanu, Płock - Katedra, 1 VI 1975, t. L, s. 4-6. 
Naród dzięki Kościołowi, który go nie opuszczał, rodzi najwyższe wartości. „Ileż razy bywało w dziejach naszego narodu - powiedział Kardynał że naród ten był osamotniony i opuszczony. Niekiedyż przez wieki nie mieliśmy własnej państwowości. [...] W czasie stupięćdziesięcioletniej niewoli, gdy nie mieliśmy własnego państwa, jedyną wiążącą i jednoczącą siłą, obok potęgi kultury ojczystej, był Kościół, religia Chrystusa. One były zawsze obecne, przytomne w dziejach narodu. Stanowiły o tym, że naród się nie wynarodowił, nie wyzbył ambicji walki o wolność, że miał poczucie należnej sprawiedliwości, a wiązał się i ratował przez nadprzyrodzoną miłość chrześcijańską. Kościół zawsze obecny w Ojczyźnie naszej przez 1000 lat, nigdy nie opuszczał narodu, a wcielony w jego życie przez Ewangelię i Krzyż, spełniał zadanie jednoczącego i miłującego wszystkich ośrodka dążeń całego narodu" 9 .

Kościół budzi wiarę w zmartwychwstanie narodu: „Polska dźwigająca się jeszcze z gruzów - przemawiał Prymas - ma potężnego ducha, którym się krzepi. Tym duchem jest Kościół Chrystusowy. Kościół - to taka siła w Ojczyźnie naszej, która nigdy narodu nie opuściła. Różne były dzieje Polski, bardzo często byliśmy bez własnych władców, bez zwierzchników, królów, prezydentów. Byliśmy nieraz wydani na łup i na niewolę, ale przez całe Tysiąclecie, chociaż państwo polskie zamierało, Kościół nie zamierał. On zawsze trwał, cierpliwie, spokojnie i wiernie. Dawał narodowi ducha, krzepił jego siłę nie tylko wiarą w Zmartwychwstanie Chrystusa i zmartwychwstanie nasze, ale w zmartwychwstanie narodu. Dodawał nadziei, potęgował miłość" ${ }^{10}$. Prymas zakładał, że religia jest najwyższą wartością. Stąd Kościół, który rozwija tę religię i realizuje ją, spełnia najszczytniejszą funkcję „pasterską" w narodzie. Strzeże naród od nacjonalizmu i szowinizmu, zespala go w jednej, wielkiej rodzinie narodów. Broni jednocześnie rodzimej kultury, dziejowych osiągnięć, właściwości narodowych oraz praw do własnych możliwości rozwojowych. W ten sposób Kościół pomaga narodowi, każdemu narodowi, znaleźć się w świecie, odkryć swoje miejsce w historii powszechnej.

Jezus Chrystus został posłany na świat i „wciela się" nie tylko w jakiś jeden naród lub w poszczególne narody w ich izolacji: czyni to w relacji do całej ludzkości i zarazem do każdego narodu, bez względu na czas istnienia tego narodu. Każdy naród ma swoją „pełnię czasu”. Cała ludzkość staje się

9 S. Wyszyński, Kościót obecny w świecie wspótczesnym i w Polsce Milenijnej, Warszawa - kościół Wszystkich Świętych, 23 I 1966, t. XXII, s. 10.

10 S. Wyszyński, Do młodzieży z Polonii angielskiej, Warszawa - Miodowa, 22 VIII 1962, t. XI, s. 6. 
w szerszym znaczeniu jakby jednym narodem, do którego przychodzi Chrystus jako widoczny znak miłości Ojca do dzieci. Kościół powszechny pomaga poddać całą rodzinę narodów pod ten znak miłości. W tym znaczeniu Prymas Polski był głosicielem Boga jako Ojca ludów i narodów.

Kościół powszechny i Kościół narodu wspiera ten gigantyczny proces usynowienia ludzi względem Boga Ojca. Każdy naród musi mieć taką „pełnię czasów". Jest to przede wszystkim moment narodzenia się Kościoła w narodzie i jego pełne ukształtowanie się w nim. „Kościół odsłania - przemawiał Ksiądz Prymas - wielką godność wszystkich ludów i narodów, stając równocześnie w obronie tej godności. Bóg - Ojciec ludów i narodów, powołując różne ludy do bytu, jest zarazem ich obrońca. [...] Bóg powołuje różne narody wprawdzie w różnych czasach, ale wszystkie powołuje do Serca Swego, do Serca Syna Bożego, który jest Królem i zjednoczeniem serc. Kościół jest ponadnarodowy. Kościół musi stać w obronie prawa wszystkich ludów i narodów do Boga. Broni prawa do Boga, prawa do Ewangelii Chrystusowej, prawa do Krzyża. Broni różnych i jednakowych praw dla wszystkich. Jest to bodaj największe osiągnięcie myśli współczesnej w rozwoju ludów i narodów"11. Ten rozwój prowadzi ostatecznie do osiągnięcia tych ideałów, np. sprawiedliwości zarówno w społeczeństwie małym, w całym narodzie historycznym, jak i w całej rodzinie narodów. „Trzeba zrozumieć - nauczał Kardynał - ducha czasów! A duch czasów to duch wyrównania społecznego wszystkich ludów i narodów, to prawo wszystkich do wolności, sprawiedliwości, miłości, szacunku i pracy. W tym duchu działa Kościół, głosząc soborową naukę o obecności Kościoła w świecie"12. Kościół jest więc duszpasterzem społecznym narodów wiodącym je ku postępowi i ideałom społecznym, ku najwyższym wartościom.

\section{W obliczu konfliktów społecznych...}

Charakterystyczną cechą duchowości Prymasa Tysiąclecia był także kult maryjny, zasługujący na odrębną, pogłębioną i krytyczną analizę. W odniesieniu do naszego tematu stwierdzić trzeba, że postać Matki Najświętszej stała w centrum odpowiedzialności za Kościół i Naród, tak jak on tę odpowiedzialność rozumiał. Oto jedno z charakterystycznych wynurzeń Księdza Prymasa dotyczące okresu święceń kapłańskich: „Urodziłem się w moim

11 S. Wyszyński, Oblaci - czyli niewolnicy Niepokalanej w stużbie Kościoła, Obra, 7 VI 1970, t. XXXIV, s. 6.

12 Tamże, s. 7. 
domu rodzinnym pod obrazem Matki Bożej Częstochowskiej i to w sobotę, żeby we wszystkich planach Bożych był ład i porządek. Całe moje życie tak wyglądało. Po święceniach kapłańskich w kaplicy Matki Bożej w Katedrze Włocławskiej uważałem za rzecz najbardziej właściwa przybyć na Jasną Górę, choć sił brakowało. Tak zaczęły się moje drogi. Prowadziły po śladach, które wydreptała Maryja, idąc przede mną jako światło, gwiazda, życie, słodkość i nadzieja, jako Wspomożycielka w ciężkiej sytuacji, niemalże Pielęgniarka i Karmicielka"13.

W odniesieniu do Kościoła, Matka Najświętsza jest wzorem troski o jego byt, rozwój i kształtowanie jego obrazu w sercach ludzkich. W odniesieniu do narodu, Matka Najświętsza jest ogniwem integrującym społeczność narodową przez wieki. Z tego przekonania wynikało, że wszystkie wielkie akcje duszpasterskie Kościoła w Polsce prowadzone przez Prymasa Tysiąclecia skoncentrowane były wokół postaci Maryi.

Duchowość chrześcijańska kardynała Stefana Wyszyńskiego łączyła się nierozerwalnie z poczuciem odpowiedzialności za Kościół wszczepiony w życie Narodu. Kościół wtedy jest akceptowany i rozumiany przez naród (nie tylko przez samych członków Kościoła), gdy wyczuwa potrzeby tego narodu, gdy nie głosi wyłącznie prawd abstrakcyjnych, ale ewangelizuje przez przenoszenie do życia doczesnego wartości religijno-moralnych; uczy patrzeć na świat oczyma Ewangelii.

Naród zaś ma prawo oczekiwać od Kościoła, który mu służy od tysiąclecia, przede wszystkim zbawienia, ale także kształtowania jego etosu na fundamencie wartości chrześcijańskich: prawdzie, sprawiedliwości, miłości, wolności.

Cechą charakterystyczną duchowości prymasa Wyszyńskiego było zatem nie oderwanie się - jak u wielu dawnych mistrzów duchowości - od „świata”, ale konsekwentna jego ewangelizacja, która służy każdemu człowiekowi i całemu narodowi. Jest to „owo głębokie” zdumienie wobec wartości i godności człowieka", o którym pisał Jan Paweł II w swej encyklice Redemptor hominis, które „nazywa się Ewangelią czyli Dobrą Nowiną. Nazywa się też chrześcijaństwem" (RH 10).

13 S. Wyszyński, Stużba w miłości, s. 25. 


\section{Podstawowe cele Wielkiej Nowenny}

Należy pamiętać, że najistotniejszym środkiem wychowania narodu polskiego w okresie powojennym, a więc owym Opus magnum pastorale Prymasa Wyszyńskiego, była Wielka Nowenna przed Tysiącleciem Chrztu Polski. Ona też rekapituluje w sobie najlepiej całą prymasowską teologię pedagogiczną narodu. Musimy więc przyjrzeć się bliżej jej podstawowym celom ogólnym. Przy tym, na razie nie chodzi o jej program i treści, lecz o jej charakterystykę jako środka i narzędzia owej niesłychanej pedagogii narodu.

Wielka Nowenna nie miała być bynajmniej jakimś triumfem Kościoła, lecz przede wszystkim wielkim rachunkiem sumienia chrześcijańskiego narodu. „Będziemy - proponował Ksiądz Prymas na jej początku - rozpatrywali zagadnienie po zagadnieniu, aby w ten sposób zrewidować i pogłębić nasz stosunek do prawd wiary Świętej i moralności chrześcijańskiej. Będziemy się pytali, czy jesteśmy wierni łasce? Na ile rodziny chrześcijańskie są prawdziwie chrześcijańskie? Czy wierne są Bogu? Czy wypełniają zadania im zlecone, aby dzieci swoje prowadzić do Chrystusa? To wszystko musi ulec jakiejś wielkiej rewizji i przemianie. Musimy się wczuć dobrze i wmyśleć w nasze sumienie, aby się przekonać czy istotnie duch Ewangelii jest duchem Narodu? Czy przypadkiem nie odmieniliśmy chociażby literki w prawie Bożym? Przecież nic nam nie wolno odmienić z Zakonu Bożego! W ten sposób pragniemy przygotować Polskę na Tysiąclecie Chrześcijaństwa. Jest to wielkie zadanie!" 14.

Ten „rachunek sumienia” nie miał oczywiście charakteru samoprzygnębiającego, ale miał na celu nawiązać - urzędowo zrywaną w ostatnich czasach - więź z chrześcijańską tradycją Polski, z jej przeszłością, z pniem rodzimej historii narodu i Kościoła.

Podobny akt nie miał równego sobie w dziejach innych narodów, zwłaszcza jeżeli idzie o wrażliwość na dolę i niedolę ludu pracującego. Ale akt ten nie został jeszcze zrealizowany w pełni. Zapewne nie wszystko udało się zrobić, za wiele było przeszkód, i to nie tylko pochodzących z naszej słabości i wad narodowych. Częściej przeszkody pochodziły od naszych zewnętrznych nieprzyjaciół, którzy dobrze rozumieli, że wykonanie Ślubów Kazimierzowych, to położenie kresu anarchii i poprawienie doli człowieka. A do tego nie chciano dopuścić. Niemniej jednak w umysłowości i duchowości naszego narodu zmieniło się to na lepsze i to w przededniu najtrudniejszych czasów, które nadchodziły dla Polski. Ta lekcja historyczna jest dla nas jed-

14 S. Wyszyński, Wielka Nowenna Tysiqclecia, Paryż 1962, s. 48-49. 
nocześnie ostrzeżeniem, aby Śluby Jasnogórskie składane przed trzystu laty nie poszły w niepamięć.

Podkreślenie więzi narodu z jego przeszłością służyć ma umacnianiu jego teraźniejszości i przyszłości. Wielka Nowenna miała być zatem wielką lekcją przyszłości narodu polskiego na drugie Tysiąclecie i na całą przyszłość. W perspektywie dzisiejszego dnia narodu i jego przyszłości na naczelnym miejscu stoi sprawa powszechnego odrodzenia: religijnego, moralnego, społecznego, kulturalnego i duchowego. Temu odrodzeniu serc i ducha może służyć i służy w sposób subtelny, na płaszczyźnie „mistyki polskiej” - kult maryjny. „Potrzeba naszemu Narodowi - czytamy na przykład - aby rozkochał się w ideale Maryi! Nie wystarczy patrzeć w Jej czyste oblicze, choćby zranione, ale trzeba w Jej oczach wyczytać wszystko co potrzebne jest do odnowy życia narodowego"15. Ten wpływ ma się rozciągnąć na całość życia narodu: „Pracujemy - nauczał prymas Wyszyński - w pierwszym roku Wielkiej Nowenny nad tym, aby Naród dochował wierności Bogu, Chrystusowi, Jego Krzyżowi i Ewangelii, Kościołowi i jego Pasterzom. Będziemy pracować nad tym, aby cały Naród był skupiony i zespolony w życiu rodziny

Zwarta bowiem rodzina jest podstawą budowania społecznego. „Rodzina rodzin" - Naród, powstaje z rodzin. Jakie będą rodziny, taki będzie i naród. Gdy rodziny będą zwarte, wierne, nierozerwalne - naszego narodu nikt nie zniszczy! Będziemy pracować nad tym, aby w rodzinach polskich było wychowanie Boże, aby dzieci nasze zdobyły cnoty, bez których nie da się utrzymać życia społecznego w pokoju; byśmy się wyzbyli wszyscy wad i nałogów, które są tak ciężką męką naszego współczesnego życia, a które mogą doprowadzić do całkowitego rozprężenia i anarchii naszego życia publicznego i społecznego. Pragniemy pracować nad tym, ażeby Polska przez miłość i sprawiedliwość społeczną doszła do tego, by wśród nas nie było głodnych, nagich ani bezdomnych; byśmy umieli się chętnie i ochoczo dzielić chlebem naszym powszednim. To jest krótki, zwięzły program Ślubów Jasnogórskich, które składamy i aż do Millenium powtarzać będziemy" ${ }^{16}$.

Odnowa ta ogarnia cały naród, wszystkie przejawy jego życia osobistego, rodzinnego i społecznego. Ma być również dojrzała i trwała, aby wejść w nowe Tysiąclecie, ubogacona w „znaki Boże”. „W naszych ślubowaniach - czytamy - które nawiązują do Ślubów Królewskich, w ślubowaniach całego Narodu mówimy, że chcemy stworzyć pomnik żywy, trwalszy od brązu, Będzie nim nasze życie chrześcijańskie. Zasady nowych ślubów pragniemy

15 S. Wyszyński, Gody w Kanie, Paryż 1962, s. 72.

16 S. Wyszyński, Wielka Nowenna..., s. 48-49. 
wykuć nie w brązie, ale w żywych sercach, myślach, w woli i na dłoniach, aby Polska była chrześcijańska nie tylko z imienia, ale z wyznania, z wiary, z życia i czynu. By każdy z nas był chrześcijaninem nawet $\mathrm{w}$ drgnieniu serca, poruszeniu woli. [...] Trzeba, aby prawdziwie odbiło się na nas światło Oblicza Bożego, aby Polska chodziła z Bożym Obliczem w swej duszy, aby życie całego Narodu miało na sobie znaki Boże. Na tym polega przygotowanie na Tysiąclecie Chrześcijaństwa i Wielka Nowenna"17.

Nowenna miała wreszcie za zadanie stworzenie pewnego całokształtu kultury duchowej narodu, kultury „chrześcijańskiej” - tak to widział prymas Wyszyński. Według niego ważniejsza w tej chwili jest w Polsce obrona kultury narodowej, ojczystej, chrześcijańskiej niż jakikolwiek inny program. Może na polskiej ziemi nie powstać wiele rzeczy - oto zdumiewająca myśl Prymasa - ta lub inna fabryka, i to jeszcze nie będzie największa strata. Gdybyśmy jednak byli narodem niemym, zalęknionym i trwożliwym, wtedy przestalibyśmy tworzyć dobra kultury, którymi ma żyć nasza dziatwa i młodzież, cała współczesność, przez którą idziemy ku przyszłości, nieznanym czasom. Jako naród, a dziś jakże doświadczony, mamy wiele do przekazania przyszłym pokoleniom. Jest w tym jednak coś najdonioślejszego - to czysta duchowość naszego narodu, który ma prawo do własnej, rodzimej, niezależnej kultury, do własnego języka, niezniekształconego i nieprzybrudzonego przez naloty śmierci: „My nie zniesiemy i nie pozwolimy - przemawiał Prymas Tysiąclecia - aby ktokolwiek uważał Naród polski za naród bez swojej własnej mocy ojczystej, bez własnej twórczości, bez dziejów i bez kultury, na którą nas, jak widać - stać"18.

Jakkolwiek Wielka Nowenna była najpotężniejszym środkiem dla chrześcijańskiego wychowania narodu polskiego, jedynym zresztą na taką skalę w dotychczasowym duszpasterstwie na całym świecie, to jednak nie wyczerpywała ona całości tych środków „pedagogii”. Przygotowywały ją, towarzyszyły jej lub wyrastały z niej liczne pedagogiczne idee i środki instytucjonalnie pomniejsze.

Pewnym wprowadzeniem do Wielkiej Nowenny było rozbudowanie myśli mariologicznej w Polsce. Wyraźnym tego znakiem było poświęcenie już w 1946 roku przez kard. Augusta Hlonda diecezji i parafii Niepokalanemu Sercu Maryi, a 8 IX 1946 roku poświęcenie się narodu polskiego. „Niepokalana Dziewico! - tak rozpoczynał się akt poświęcenia - Boga Matko Przeczysta! Jak ongiś po szwedzkim najeździe król Jan Kazimierz Ciebie za Patronkę

17 Tamże, s. 79.

18 S. Wyszyński, Z rozważań nad kulturq ojczysta, Poznań-Warszawa'1979, s. 244-245. 
i Królowę państwa obrał i Rzeczpospolitę Twojej szczególnej opiece i obronie polecił, tak w tę dziejową chwilę my, dzieci Narodu polskiego, stajemy przed Twym tronem i hołdem miłości, czci serdecznej i wdzięczności Tobie i Twojemu Niepokalanemu Sercu poświęcamy siebie, naród cały i wskrzeszoną Rzeczpospolitę, obiecując Ci wierną służbę, oddanie zupełnie oraz cześć dla Twych świątyń i ołtarzy. Synowi Twojemu, a naszemu Odkupicielom, ślubujemy dochowania wierności Jego nauce i prawu, obronę Jego Ewangelii i Kościoła, szerzenie Jego Królestwa [...] Narodowi polskiemu uproś stałość w wierze, świętość w wierze, zrozumienie posłannictwa [...] Daj tej polskiej Ziemi, przesiąkniętej krwią i łzami, spokojny i chwalebny byt w prawdzie, sprawiedliwości i wolności" 19 .

Mariologia i pobożność maryjna nie była oderwana od chrystologii i duszpasterstwa chrystologicznego, które również miało wykorzystać wszystkie religijne siły Kościoła i potrzeby narodu. Poza podkreślaniem „duszpasterstwa chrystologicznego" przez "mariologiczne”, chodzi tu jeszcze o kult Chrystusa Króla, Serca Jezusowego i inne. Idea chrystologicznej pedagogii narodu u prymasa Wyszyńskiego realizuje się więc w znaku Chrystusa Króla rozpoczętej już przez prymasa Hlonda. Każdy rok ma określony temat w ramach powstałej przy tej idei „Społecznej Krucjaty Miłości”. I tak na przykład w roku 1969 „Społeczna Krucjata Miłości” była realizowana jako „Krucjata dobrego słowa”, w 1970 - celem oddziaływania była obrona życia nienarodzonych, w 1971 - młodzież w służbie Kościoła, narodu i każdego człowieka. W roku zaś 1972 w zakresie „Społecznej Krucjaty Miłości” było wezwanie do pomagania młodszemu pokoleniu. Tematycznie chrystologiczna pedagogia narodu u prymasa Wyszyńskiego ściśle jest związana z mariologiczną i hasłami Wielkiej Nowenny; chrystologiczna jest fundamentem, inspiracją dla mariologicznej pedagogii.

Pedagogii mariologicznej towarzyszyły ciągle różne pomniejsze formy. Należało do nich rozbudzenie ruchu pielgrzymkowego, zwłaszcza na Jasną Górę, często według stanów i zawodów; nawiedzenie Obrazu Matki Bożej Jasnogórskiej w diecezjach, parafiach, rodzinach; pokutno-błagalne akcje na rzecz zagrożonych odcinków życia moralno-religijnego w kraju; pomoc dla Ojca Świętego przez wyznanie wiary słowami Pawła VI w czasie diecezjalnych pielgrzymek na Jasną Górę. Na szczególną uwagę zasługują również „Soboty Królowej Polski”. Jest to wykorzystanie nabożeństwa pierwszych sobót miesiąca jako dni poświęconych Maryi i ubogacenie ich specjalnie

19 Akt poświęcenia się Narodu polskiego Niepokalanemu Sercu Najświętszej Maryi Panny, LPP, s. 23. 
kultem Jej Niepokalanego Serca. Nabożeństwa te ukierunkowano intencją ogólną: o królowanie Maryi w narodzie polskim oraz o wypełnienie Jasnogórskich Ślubów Narodu. Ponadto dla każdej soboty była intencja szczegółowa w postaci jednego z punktów Ślubowań. W ten sposób pierwsze soboty przygotowywały cały naród do ponowienia aktu Ślubowań w dniu 5 maja 1957 roku. Odtąd treścią Wielkiej Nowenny zapełniono wszystkie pierwsze soboty miesiąca pod nazwą „Sobót Królowej Polski”. Należy również pamiętać o idei Prymasa dotyczącej „Apelu Jasnogórskiego”. Składowymi elementami apelu są: duchowe „stawienie się” przed Królową Polski, odmówienie „Pod Twoją obronę” oraz jednej tajemnicy różańca za Kościół i naród, krótki rachunek sumienia, trzykrotne wezwanie „Maryjo Królowo Polski, jestem przy Tobie, pamiętam, czuwam."

Z Wielkiej Nowenny wypływały pewne idee szczegółowe, jak „Oddanie się Narodu w niewolę Maryi” oraz idea „Pomocników Maryi Matki Kościoła”. Idea oddania się Matce Bożej sięga początkiem oddania narodu Niepokalanemu Sercu Maryi na Jasnej Górze w 1946 roku, „Ślubów Jasnogórskich" w 1956 roku oraz wielu innych aktów oddania się pod macierzyńską opiekę Maryi, jakie miały miejsce w okresie Wielkiej Nowenny. Milenijny Akt z 3 V 1956 roku oddał całą Ojczyznę i wszystkich Polaków na świecie, w macierzyńska „niewolę” miłości Maryi za wolność Kościoła. Akt ten miał swoje uzasadnienie eklezjologiczne, u podstaw którego leżało ufne zawierzenie Matce Kościoła. Oddanie za Kościół wymaga bowiem wielkiej wrażliwości na jego potrzeby i problemy we współczesnym świecie. Narodowy akt oddania nie mógł pozostać tylko jednorazowym aktem historycznym. Jego duch musiał być realizowany przez poszczególnych ludzi, pragnących pomagać Kościołowi przez Maryję. Toteż nie sposób zrozumieć pełnego włączenia się w Akt Milenijny i lepszej jego realizacji, bez osobistego oddania się Maryi i postępowania zgodnie z jego wymaganiami. Oddanie osobiste jest natomiast doskonałe wtedy, gdy zawiera w sobie również cele apostolskie. Dlatego na progu drugiego tysiąclecia następowały akty oddania się w „macierzyńską niewolę" wszystkich stanów i zawodów, diecezji, seminariów duchownych, parafii itp. Stąd wyrosła idea „Pomocników Maryi Matki Kościoła". Jest ona czynnym włączeniem się poszczególnych ludzi w Milenijny Akt Narodu i przyjęciem osobistej odpowiedzialności za Kościół według wskazań Soboru. Chodzi tu o świeckich katolików wychowanych w duchu odpowiedzialności za Kościół, pomagających Kościołowi z zachowaniem ładu hierarchicznego, ustalonego w Kościele.

Poza tym nie można zapominać, że Wielka Nowenna zbiegła się z Soborem Watykańskim II, co z jednej strony dodało Nowennie nowych treści, a z drugiej - poszerzyło wiele jej owoców na cały świat katolicki, w „skarbiec 
Kościoła powszechnego". Lata 1962-1965 były przygotowaniem bezpośrednim do Milenium i przebiegały równolegle z kolejnymi sesjami Vaticanum II. Z inicjatywy Księdza Prymasa, Episkopat Polski postanowił stworzyć wyraźną więź między pracami Soboru, a przygotowaniem do Tysiąclecia. W ten sposób ukształtował się, w ramach odnośnych lat Wielkiej Nowenny przed Tysiącleciem, czteroletni program duszpasterski, który miał na celu związanie Kościoła w Polsce z najbardziej żywotnymi sprawami Kościoła powszechnego, podejmowanymi przez Sobór. I tak każda parafia zobowiązana była do urządzania w kościele tak zwanego „dnia czuwania”. O północy odprawiano mszę świętą. Czas przed i po północy zapełniały: modlitwa różańcowa, adoracje dla poszczególnych stanów, ponowienie aktu oddania się Matce Bożej. Program czuwania przewidywał ponadto trzy nauki w trakcie nabożeństwa oraz „czyn soborowy” w postaci aktu powszechnego przebaczenia sobie win i uraz, pojednanie się ze wszystkimi w ramach rodziny, sąsiedztwa, parafii w duchu soborowego zjednoczenia i miłości. Przez całą dobę przed wystawionym obrazem Matki Bożej Jasnogórskiej płonęła świeca, jako symbol czuwania parafii. Nadto, w dniu czuwania delegacje poszczególnych parafii jechały na Jasną Górę, by tam modlić się w intencji Ojca Świętego i soboru.

Sobór Watykański II zdecydował się włączyć odrębny z początku schemat poświęcony Maryi do centralnego swego dokumentu, jakim była Konstytucja dogmatyczna o Kościele. W ten sposób VIII rozdział tej doktrynalnej Konstytucji uczy o Matce Bożej obecnej w tajemnicy Chrystusa i Kościoła. I na tym odcinku prymas Wyszyński odegrał doniosłą rolę. W imieniu Episkopatu złożył Ojcu Świętemu Pawłowi VI memoriał, w którym prosił o wprowadzenie do nauczania soborowego określenia „Matka Kościoła”. Chodziło bowiem nie tylko o sam tytuł, ale o wprowadzenie praktycznych i duszpasterskich konsekwencji wynikających z tego tytułu: o poświęcenie Kościoła i świata macierzyńskiej opiece Bogarodzicy. I tak, na zakończenie trzeciej sesji Vaticanum II, 21 XI 1969 roku, Paweł VI ogłosił, że Matka Chrystusa jest zarazem Matką Kościoła. Był to niewątpliwie osobisty sukces kardynała Wyszyńskiego i Episkopatu Polskiego na Soborze Watykańskim II.

I wreszcie, po zakończeniu Wielkiej Nowenny nie skończyła się bynajmniej akcja dalszej „pedagogizacji” narodu. Ksiądz Prymas kontynuuje dalej następujące idee: umieszczenie w każdej świątyni parafialnej Milenijnego Aktu Oddania przywiezionego z Jasnej Góry przez delegację parafialną; apel o modlitwy o oddanie świata Maryi Matce Kościoła; Tygodnie Miłosierdzia Chrześcijańskiego, co roku z nowym hasłem; rocznice Soboru Watykańskiego II i inne. Umacnianie owoców Wielkiej Nowenny przebiega w dalszym ciągu poprzez wędrówkę Obrazu Jasnogórskiego po rodzinach w kraju i za 
granicą - w rodzinach polskich; ponawianie Ślubów Jasnogórskich co roku w kościołach parafialnych i na Jasnej Górze w dniu 3 maja przez Episkopat u imieniu całego narodu; organizowanie modlitw za papieża, obecnie Jana Pawła II oraz przygotowanie narodu do jubileuszu sześćsetlecia Cudownego Obrazu na Jasnej Górze. To wszystko zbliża naród do perspektyw Kościoła uniwersalnego.

Wychowanie narodu przez Kościół nie ustaje, choć środki i sytuacje ciągle się zmieniają. Niemniej po umocnieniu Kościoła polskiego ad intra, Ksiądz Prymas kładzie większy nacisk na wzmożenie wkładu Kościoła polskiego w Kościół powszechny i w całą rodzinę narodów świata. Stąd zrodziły się u niego liczne inicjatywy powszechno-kościelne, jak choćby pojednawcza i chrześcijańska wizyta w RFN, działalność na rzecz pokoju światowego, interwencja przeciwko bezprawiu i terroryzmowi na świecie, zacieśnienie związków z całą Polonią świata itp. Ksiądz prymas Wyszyński wychodził tu z ogólnego założenia, że nic tak nie wychowuje narodu ku chrześcijaństwu i humanizmowi jak służba narodu całemu światu i jego aktywne życie na wspólnym theatrum całej rodziny ludzkiej.

Na zakończenie naszych rozważań nad duchowością kardynała Stefana Wyszyńskiego w świetle odpowiedzialności za Kościół i naród niech posłużą słowa modlitwy Jana Pawła II wypowiedziane na audiencji środowej w dniu 25 V 1983 r.: „Pani Jasnogórska! Pragnę dzisiaj polecić Twemu Macierzyńskiemu sercu - Wspomożycielko wiernych śp. Kardynała Stefana Wyszyńskiego - Prymasa Polski, którego Ojciec Niebieski dwa lata temu odwołał do wieczności. Było to w dniu 28 maja 1981 roku, w samą uroczystość Wniebowstąpienia Pańskiego. Jakża wymowny dzień! Jak wiele mam mówić o tym, że data śmierci jest zarazem datą narodzin do pełnego życia w Bogu. Odszedł od nas w dzień Wniebowstąpienia Prymas Tysiąclecia, Człowiek, któremu dane było służyć na polskiej Ziemi w okresie przełomowym i trudnym. [...] Pozostawił po sobie wielkie zaiste dziedzictwo. Oby to dziedzictwo trwało i w nas. Oby Kościół i Naród pozostał mocny dziedzictwem Kardynała Stefana Wyszyńskiego" 20.

20 Badź z nami w kazdy czas. Modlitwy Jana Pawła II za Ojczyznę, Libveria Editrice Vaticana 1983, s. 95. 